\title{
Matrix Tools for Cost Estimate of Construction Products
}

\author{
Kuladzhi T.V. \\ Higher School of Economics, Management and Law \\ Northern Federal University named M.V. Lomonosov \\ Arkhangelsk, Russia \\ kuladzhit@list.ru
}

\author{
Aliyev S.A. \\ Construction Department \\ Grozny State Oil Technical University \\ named M.D. Millionshchikov \\ Grozny, Russia \\ asa-fenix@mail.ru
}

Abukhanov A.Z.

Construction Department

Grozny State Oil Technical University

named M.D. Millionshchikov

Grozny, Russia

abuhanov54@mail.ru

\author{
Murtazayev A.T. \\ Construction Department \\ Grozny State Oil Technical University \\ named M.D. Millionshchikov \\ Grozny, Russia \\ ma_taipovich@mail.ru
}

\author{
Mintsayev M.Sh. \\ Grozny State Oil Technical University \\ named M.D. Millionshchikov \\ Grozny, Russia \\ ranas@rambler.ru
}

Salgiriyev R.R.

Institute of Economy and Law

Grozny State Oil Technical University named M.D. Millionshchikov

Grozny, Russia

rsalgiriev@mail.ru

\author{
Nakhayev M.R. \\ Construction Department \\ Grozny State Oil Technical University \\ named M.D. Millionshchikov \\ Grozny, Russia \\ mr-nakhaev@mail.ru \\ Ismailova Z.H. \\ Construction Department \\ Grozny State Oil Technical University \\ named M.D. Millionshchikov \\ Grozny, Russia \\ ismailova-z-h@mail.ru
}

\begin{abstract}
The present stage of innovative development of the country is characterized by considerable changes caused by the introduction of digital technologies into the economy and the social sphere. The measures aimed to improve the institutional conditions of business, production of innovative products taking into account information technologies are stipulated in the current normative legal acts of the Russian Federation: On industrial policy in the Russian Federation, Development strategy of information society of the Russian Federation for 2017-2030, Digital economy of the Russian Federation, etc. The activity of the Ministry of Digital Development, Communication and Mass Communications of the Russian Federation, the Government Commission on Digital Development, Use of Information Technologies for the Improvement of Quality of Life and Business Conditions, etc. are focused on the coordination of issues related to the development of digital economy ecosystems. Modern conditions pose the need for methods of operational (simultaneous) definition of cost indexes and efficiency of planned or forecast production, including the industry of construction materials and structures. Such properties are typical for professor M.D. Kargopolov's matrix formula developed on the basis of inputoutput method of V.V. Leontyev and the output and finance plan
\end{abstract}

of the Soviet period, which clearly defines all cost indexes (cost value) of production. This formula is recommended for use in management accounting, controlling, internal audit, etc. to assess and make decisions on innovative production efficiency, including construction materials (made using energy- and resource-saving technologies, composite materials, nanotechnologies, etc.) under certain market conditions by various legal entities, including organizations joining a cluster.

Keywords-cost value, innovative production, cluster, balance method of V.V. Leontyev, professor M.D. Kargopolov's matrix formula, production digitalization

\section{INTRODUCTION}

At the meeting of the State Council of the Russian Federation On the development of a construction complex and improvement of town-planning activity in the Russian Federation (2016) [1] the Russian President V.V. Putin noted that the construction industry "is one of the most dynamic and perspective segments of the market, which accounts for nearly $6 \%$ of the country's GDP", however "the current budget- 
normative base is obsolete and requires accurate, reasonable and authentic cost data with regard to design and construction. As a result it is impossible to proof the validity and efficiency of state investments to the construction of various objects" [1]. Recently, the Ministry of Construction, Housing and Utilities of the Russian Federation has approved the decree [2] on the plan for development, update and revision of budget standards for 2018 ensuring the development of 1184 new budget standards, 148 of which - out of state funds, and 1036 - out of extrabudgetary funds (with the revision of 690 budget standards).

The program on the Digital Economy of the Russian Federation [3] implies the introduction of digital economy since "digital data are critical for production in all spheres of social and economic activity, thus ensuring competitiveness enhancement of the country, improving the quality of life of its citizens, and providing for the economic growth and national sovereignty". Modern scales of introduction of digital technologies into the economy and the social sphere are stipulated in the Decree of the Russian President On national objectives and strategic tasks of the development of the Russian Federation until 2024 [4], as well as in resolutions of the Federation Council of the Federal Assembly of the Russian Federation On urgent development issues of the sphere of communication and information technologies in the conditions of digital economy in the Russian Federation [5], On measures of the Government of the Russian Federation to achieve national objectives of the development of the Russian Federation until 2024 [6], in the resolution Priority areas of the Government of the Russian Federation until 2024 [7], etc., which ensure the introduction of regulations on national projects (programs) taking into account strategic objectives of spatial development of the Russian Federation until 2035 and production digitalization at the present stage. Thus, "over 50 draft federal laws concerning legislative recognition of information as an object of civil rights" are developed according to ten thematic sections taking into account the "large-scale operational program of economic development of a new technological generation" [5]. The federal state information system of informatization control considers the issues of "a single information space aimed to support administrative decisions in the field of public administration of information and communication technologies" designed or utilized by executive authorities of the Russian Federation, state and municipal unitary enterprises, institutions, etc. [8]. The issues of modernization of the economy with the focus on competitiveness enhancement and reduction of the level of import dependency of the country, as well as digitalization of innovative technologies for infrastructure development of the economic complex of the country are also reflected in the General agreement between the All-Russian Trade Union Associations, the All-Russian Associations of Employers and the Government of the Russian Federation for 2018-2020 [9]. In accordance with item 4, Art. 14 On industrial policy of the Russian Federation [10], the state information system contains information on current state of the industry and forecast of its development, on state and municipal programs implying the formation and implementation of industrial policy in the country, etc.

It shall be noted that the Strategy on the Development of
Construction Materials and Industrial Housing Construction until 2020 (section III. Criteria and indicators of problem solutions in industry) [11] provides for the creation of "territorial innovative clusters ensuring the implementation of a complete innovative cycle from scientific research to serial production in Siberian, Far East and North Caucasian federal districts" to improve the efficiency of R\&D and innovative activity in the country [11], while item 3 of the Strategy on the Development of Construction Materials and Industrial Housing Construction until 2020 and further prospect until 2030 (as amended of 23.11.2016) [12] recommends the executive authorities of territorial subjects of the Russian Federation to apply the provisions of this strategy as an industry document of strategic planning.

According to item 3, Art. 20 [10], the industrial cluster is the association of entities "in the field of industry bound by relations in a certain sphere due to proximity and functional dependence", located in the territory of one territorial subject of the Russian Federation or several territorial subjects of the Russian Federation. Besides, the Forecast of scientific and technological development of the Russian Federation until 2030 notes that the following influence the development of innovative clusters: globalization, development of digital technologies, bio- and nanotechnologies, etc.

Traditionally, the cluster policy of different countries reflects the specifics of economic policy of the country taking into account strategic objectives of innovative and competitive positioning in the world markets [13. pp. 46-50]. Thus, the system based on network structures was the main issue discussed at the First World Congress on Clusters in Paris (2001) held by the Organization for Economic Cooperation and Development (OECD) and others (LEED, DATAR, UNIDO, etc.). Therefore, the cluster strategies and programs implement the changing tool kits containing analytical approaches and methods reflecting various policies of different fields: regional, industrial, innovative and technological $[13,14]$.

In [15] prof. A.V. Babkin, et al. noted that "the wave of clusters of the present era (starting from 1970s) is increasing to disintegration of vertically integrated companies, mainly caused by drastic increase of production complexity - first of all in mechanical engineering". Modern tools to assess the competitiveness of made and sold products are required in the conditions of production digitalization for the analysis of innovative production efficiency of any enterprise within the construction industry. D.Sc. R.T. Sirazetdinov considered the mathematical models to assess the economic activity of a cluster [16]: the universal structural model of a standard economic cluster (UMEC) and the mathematical model of an economic cluster (MMEC), which algorithms allow "identifying and studying certain economic clusters".

The given paper recommends the Professor M.D. Kargopolov's universal matrix formula as the tool providing for visualization of cost indexes and simultaneous definition of all required indicators of the estimate cost (cost value) of production to assess and forecast cost indexes of production in various organizations, including a cluster, in the conditions of modern approaches to production digitalization of the economic complex [17-19]. Material matrix models allow analyzing the 
economic system taking into account the balance between the quantity of production manufactured by economic subjects and the cumulative demand for them, since the balance model represents the system of equations, each of which expresses the balance requirement between the quantity of production made by certain economic objects and the cumulative demand for this production. If the balance equation of V.V. Leontyev, the Nobel Prize Laureate in Economy, is widely viewed as a tool of microforecasting of production output at national and world levels, then the Professor M. D. Kargopolov's matrix formula is recommended as a tool of microforecasting in certain economic units - corporations, households, etc., including economic subjects of a cluster [20].

\section{METHODS AND MATERIALS}

At present, the objectives and tasks of information and communication technologies in Russia are linked to the development of modern digital economy. The definition of the concept "digital economy" (item 4 [3]) refers to digital economy as the economic activity with "digital data, processing of large volumes and use of results that allow increasing the efficiency of different types of production, technologies, equipment, storage, sale, delivery of goods and services in comparison with traditional business patterns" being the key factors of production [3]. The development of digital environment and key institutes implies "conditions for breakthrough and advanced cross-cutting digital platforms and technologies". Among other main cross-cutting digital technologies the Program [3] lists the following: big data; new production technologies; industrial Internet; elements of robotics and sensorics; wireless communication technologies, etc. Hence, it implies the interaction of all three levels influencing the life of citizens and society: markets and branches of economy as fields of activity fostering the interaction between suppliers and consumers of goods, works and services; platforms and technologies forming competences within various fields of activity - markets and branches of economy; environment creating conditions for the development of platforms and technologies with efficient interaction of subjects of markets and branches of economy, including standard regulation, information infrastructure, staff and information security.

According to the law On Information, Information Technologies and Information Security, the information technologies represent "processes, methods of search, collection, storage, processing, delivery, dissemination of information and ways to implement such processes and methods" [21].

Some sub-programs within the state program of the Russian Federation on Industrial Development and Competitiveness Enhancement [22] are aimed at the development of innovative production in Russia: development of production of traditional and new materials to form the basis for the creation and development of modern industry of composite materials thus ensuring global competitiveness; facilitation of investment projects and support of high-tech production within civil engineering; development of industrial infrastructure and infrastructure to support industrial activity for the benefit of advanced development of "activity in the sphere of industry in territorial subjects of the Russian Federation aimed to strengthen their industrial potential and ensure long-term social and economic growth", etc. This document [22] implies the monitoring of competitiveness of innovative products, including construction materials and structures with the use of composite materials and with further analysis of their production efficiency in regional conditions.

According to academician S.Yu. Glazyev, the present stage of economic development is characterized by the transformation of information into the primary source of development, and science - into the leading productive force continuously generating technological opportunities of a different level, since "half of all information utilized by an individual these days is obtained and transformed in recent 15 years, and its total amount increases twice every 7 years" [23].

The Doctor of Economics Yu.V. Yakovts in his work Global Economic Transformations of the $21^{\text {st }}$ Century [16] said that the first quarter of the $21^{\text {st }}$ century is characterized by "prerequisites for the implementation of innovative and breakthrough scenario of future global transformations..." and requires the cornerstones of the post-industrial scientific paradigm developed in $1920 \mathrm{~s}-1930$ s of the $20^{\text {th }}$ century: theory of anticipation and doctrine of cycles, crises and innovations of Nikolay Kondratyev and Joseph Schumpeter, doctrine of noosphere by Vladimir Vernadsky and Nikita Moiseyev, civilization approach to history and future of economy and society by Pitirim Sorokin, Arnold Toynbee, Fernand Braudel, balance method of macroforecasting by Vasily Leontyev [24]. In his Economic essays. Theory, study, facts and policy V.V. Leontyev indicates the macroeconomic approach to the economy, when "the methods of quantitative analysis are not simply the methodological methods used by researchers: they represent the subject matter" [25].

In his report the Matrix formula of production cost and price per unit of production (works, services) (2012) the Doctor of Economics M.D. Kargopolov showed that in the balance equation by V.V. Leontyev in the matrix form: $X=(E-A)^{-1} Y$, the main and only possible option to solve the balance model is the option where the levels of production of final (commodity) products $(Y)$ are known (set), and the levels of gross output $(X)$ are required (estimate). The production function with "material matrix balance models and methods forming its basis" may be used to define the "optimum level of production costs and output". The input-output method developed by the Nobel Prize Laureate in Economy V. Leontyev forms the basis and the solution of matrix balance models. This is the method of intercomparison of available material, labor and financial resources and the demand for them [17].

It is noted in [26] that the current methods to define the estimated cost of construction products "reflect the methods of averaging, including calculations of indexes, which will never result in the actual cost of construction objects even within a single settlement due to cost differences of a zero cycle constructive solutions dependent on the relief or geological and hydrogeological conditions of the construction site, logistics, and other costs". Therefore, to calculate the full cost or required market value of innovative construction products the works [13, 20-27] recommend to use the matrix formula of professor M.D. 
Kargopolov developed taking into account the balance equation of V.V. Leontyev and the output and finance plan of the Soviet period [28].

\section{RESULTS}

The Development strategy of information society in the Russian Federation for 2017-2030 [29] states that Russia still lags behind the leading countries thus holding the $38^{\text {th }}$ place in terms of economic and innovative results of digital technologies due to gaps in "the regulatory base for digital economy and insufficient environment for business and innovations and, hence, due to low application level of digital technologies by business structures". According to the report of the World Economic Forum on Global Competitiveness, in 2016-2017 Russia took the $43^{\text {rd }}$ place after such countries as Switzerland, Singapore, the United States of America, the Netherlands, Germany, Sweden, Great Britain, Japan, Hong Kong and Finland [1], etc. in the international ranking on economic competitiveness due to insufficient business development and low level of innovations in the global digital market. To analyze the development of digital economy the [1] recommends to use the international I-DESI index published by the European Commission in 2016, which utilizes data from OECD, UN, ITU, etc., with such index components as communication, human capital, use of Internet, introduction of digital technologies into business and digital services for the population [1], since the digital economy within the Strategy [29] is defined as the economic activity with key digital factors of production.

The works [17-19] show that any economic system may be considered as the scheme of interacting objects producing a certain item (as part of X), one part (W) of which is consumed by other objects of the given economic system, and another part of production $(\mathrm{Y})$ is removed beyond the system as its final product. Hence, the following are identified within the general production structure of an enterprise to assess the cost value and efficiency of each production item in the scheme of transformation of production resources into commercial products within production (P) of the enterprise (Fig. 1) [19]:

According to this scheme (Fig. 1), the primary resources (PR) are bought for money (M) at wholesale and purchasing or market prices, and the sale of final products $(\mathbf{Y})$ in the market shall bring new money (M') for the enterprise and for profitable organizations (enterprises) the following condition shall always be satisfied: $\mathbf{M}^{\prime}>\mathbf{M}$. Here the value of domestic production resources $\mathbf{D P R}(\mathbf{W})=\mathbf{X}-\mathbf{Y}$ represents domestic production of the economic subject, which is used for internal production consumption and reflects costs of domestic production resources (DPR) at a technological and (or) intrafactory turnover, and unlike primary resources, the DPR unit cost represents the estimated cost (full cost) of production of each DPR unit (works, services). Professor M.D. Kargopolov noted that "the more complex the production, the more difficult it is to calculate the actual cost and, hence, to ensure high quality of all economic calculations at the enterprise" [19]. a) at the input - resources required for production, including primary resources (PR) and domestic production resources (DPR);

b) domestic production of final products representing the complex of workshops, sites, offices, crews, services, work places and other divisions performing certain technological operations within the production on the transformation of production resources into products (defined as P), i.e. a set of technological operations, each of which makes one type of product;

c) at the output - end products (results) $-\mathbf{Y}$.

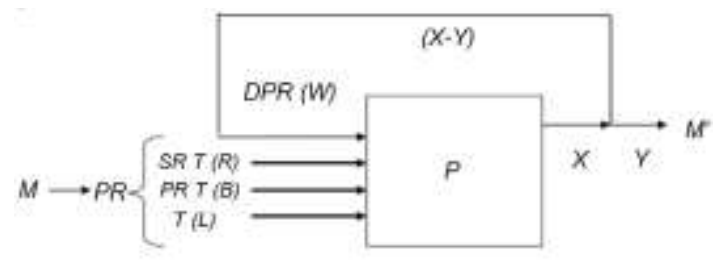

Fig. 1. Diagram of conversion of production resources into products in the process of production.

The Professor M.D. Kargopolov's matrix formula looks as follows [17-19]: $\mathbf{P}=(\mathbf{E}-\mathbf{A})^{\mathbf{T}-1} \cdot \mathbf{D}^{\mathbf{T}} \cdot \mathbf{C}$, where: $\mathbf{P}=\left\|\mathbf{p}_{\mathrm{j}}\right\| ; \quad j=\overline{1, n}-$ required column vector of production (full) cost per unit of production (works, services); $\mathbf{E}-$ single matrix $\mathrm{n} \times \mathrm{n} ; \mathbf{A}=\left\|\mathrm{a}_{\mathrm{ij}}\right\|$, $i=\overline{1, n}, j=\overline{1, n}-$ matrix of $\mathrm{n} \times \mathrm{n}$ consumption of domestic production resources; $\mathbf{D}=\left\|\mathrm{d}_{\mathrm{ij}}\right\|, \mathrm{i} \in \mathrm{L} \mathrm{U} \mathrm{R}, j=\overline{1, n}$ - matrix of primary resources consumption ( $L$ - variables, $R$ - constants), ${ }^{\mathbf{T}}$ - transposition sign for matrixes $A$ and $D ; C=\left\|c_{i}\right\|, i \in L U R-$ column vector of wholesale and purchasing prices of primary resources;

In Microsoft Office Excel the target value of $\mathbf{P}$ vector elements of the Professor M.D. Kargopolov's matrix formula are defined as follows: = MMULTIPL (MMULTIPL (MREV (E- TRANSP (A)); TRANSP (D));C).

This formula uses standard codes: MMULTIPL calculates the matrix product stored in structure, MREV defines the inverse matrix (stored in structure), and TRANSP generates transposable structure [30]. The cost indexes of production according to the Professor M.D. Kargopolov's matrix formula in Microsoft Office Excel are always defined simultaneously with pinpoint accuracy.

This is traditionally followed by an example of the specified matrix formula to calculate all production costs of end products - reinforced concrete products. It shall be noted that end products and their components may be produced by different legal entities, including those joining the innovative territorial cluster (for example, small enterprises producing concrete materials, etc.).

Thus, the design charts include the volumes of primary resources required for the production of domestic production resources (DPR) variably considered as the intermediate production of small enterprises being subjects of a cluster on the production of simple items. 


\section{CONCLUSIONS}

1. Currently, the Russian Federation reconsiders the issues of production digitalization required to tackle the efficiency and competitiveness of products of any legal entity, including subjects joining clusters. The present stage of construction materials and structures requires active participants of innovative territorial clusters formed in territorial subjects of the Russian Federation.

2. For economic-mathematical microforecasting of cost indexes, including the cost value of innovative construction products within a cluster, it is recommended to use the Professor M.D. Kargopolov's matrix formula, which simultaneously and with pinpoint accuracy allows defining all production cost indexes.

3. In the economic practice the balance equation of the Nobel Prize Laureate in Economy V.V. Leontyev may be considered as a tool of macroforecasting of production output at national and world levels, and the Professor M.D. Kargopolov's matrix formula is recommended as a tool of microforecasting of activity of economic subjects, including a cluster and enterprises of the branch of construction materials and structures.

\section{References}

[1] On meeting of the State Council of the Russian Federation with the following agenda: On the development of construction complex and improvement of town-planning activity in the Russian Federation: Decree of the Russian President No. 112-rp of 07.05.2016. Access mode: http://publication.pravo.gov.ru/Document/View/0001201605080001.

[2] On approval of the cost estimate plan (update, revision) for 2018. Order of the Ministry of Construction, Housing and Utilities of the Russian Federation No. 152/pr of 20.03.2018. URL: http://base.consultant.ru.

[3] On the approval of the Digital Economy of the Russian Federation program. Order of the Government of the Russian Federation No. 1632-r of 28.07.2017 URL: http://base.consultant.ru.

[4] On national objectives and strategic tasks of the development of the Russian Federation until 2024. Decree of the Russian President No. 204 from 07.05.2018 (as amended on 19.07.2018). URL: http://base.consultant.ru/.

[5] On urgent development issues of the sphere of communication and information technologies in the conditions of digital economy in the Russian Federation. Resolution of the Federation Council of the Federal Assembly of the Russian Federation No. 79-SF of 21.03.2018. URL: http://base.consultant.ru/.

[6] On measures of the Government of the Russian Federation to achieve national objectives of the development of the Russian Federation until 2024. Resolution of the Federation Council of the Federal Assembly of the Russian Federation No. 237-SF of 27.06.2018. URL: http://base.consultant.ru/.

[7] Priority areas of the Government of the Russian Federation until 2024 (approved by the Government of the Russian Federation on 29.09.2018). URL: http://base.consultant.ru/.

[8] On federal state information system of informatization control. Resolution of the Government of the Russian Federation No. 1235 of 14.11.2015 (as amended on 25.09.2018). URL: http://base.consultant.ru.

[9] General agreement between the All-Russian Trade Union Associations, the All-Russian Associations of Employers and the Government of the Russian Federation for 2018-2020. URL: http://base.consultant.ru/.

[10] On industrial policy in the Russian Federation. Federal law No. 488-FZ of 31.12.2014 (as amended on 27.06.2018). URL: http://base.consultant.ru.

[11] On approval of the Strategy on the Development of Construction Materials and Industrial Housing Construction until 2020. Decree of the Ministry of Regional Development of the Russian Federation No. 262 of 30.05.2011. URL: http://base.consultant.ru.
[12] On the Strategy on the Development of Construction Materials and Industrial Housing Construction until 2020 and further prospect until 2030. Decree of the Government of the Russian Federation No. 868-r of 10.05.2016 (as amended on 23.11.2016). URL: http://base.consultant.ru.

[13] T.V. Kuladzhi. Cluster economy: matrix tools to assess the production efficiency: monograph. Arkhangelsk: NArFU named M.V. Lomonosov, 2014.

[14] Analysis of foreign experience on increasing branch, regional and national competitiveness based on clusters. Copyright. Institute of Regional Innovative Systems. http://www.innosys.spb.ru/?id=1093.

[15] A.V. Babkin, and A.O. Novikov, "Cluster as a subject of economy: importance, current state, development", Scientific and technical bulletin of SPbPU. Economic sciences, No. 1 (235), pp. 9-29, 2016.

[16] R.T. Sirazetdinov, A.A. Brazhkina, "Universal structural model of a standard economic cluster", Management of Big Systems, No. 29, pp. 152-166, 2010.

[17] M.D. Kargopolov, "Matrix formula of production cost and price per unit of production (works, services)", Proceedings of the International scientific conference: Mathematics, economy, management: 100 years from the birth of L.V. Kantorovich. SPb: St.Petersburg State University publishing house, pp. 146-147, 2012.

[18] M.D. Kargopolov. Interoperational balances of production costs and results: theory and practice. Arkhangelsk: ASTU, 2001.

[19] M.D. Kargopolov. Balance methods in economic estimates at an enterprise: study manual. Arkhangelsk: NArFU, 2012.

[20] T.V. Kuladzhi, "Matrix tools of microforecasting within the innovative cluster", Scientific and technical bulletin of SPbPU. Economic sciences, No. 4 (246), pp. 264-279, 2016.

[21] On information, information technologies and information security. Federal law No. 149-FZ of 27.07.2006 (as amended on 31.12.2017). URL: http://base.consultant.ru.

[22] On approval of the state program of the Russian Federation Industrial development and competitiveness enhancement. Resolution of the Government of the Russian Federation No. 328 of 15.04.2014 (as amended on 01.10.2018). URL: http://base.consultant.ru.

[23] S.Yu. Glazyev. Russia is able to join the new technological setup. www.business-gazeta.ru/article/66460.

[24] Yu.V. Yakovets. Global economic transformations of the $21^{\text {st }}$ century. Moscow: Economy, 2011.

[25] V. Leontyev. Economic essays. Theory, study, facts and policy. Moscow: Political literature, 1990.

[26] T.V. Kuladzhi. Methodology of assessment of constructive decisions within a construction complex: monograph. Arkhangelsk: NArFU publishing house, 2014

[27] T.V. Kuladzhi, "Algorithm of microforecasting of competitive construction production in a cluster", MSCU Bulletin, vil. 12, Iss. 3 (102), pp. 273-283, 2017.

[28] V.V. Kossov. Interindustry models. Moscow: Economy, 1973.

[29] On the development strategy of information society in the Russian Federation for 2017-2030. Decree of the Russian President No. 203 of 509.05.2017. URL: http://base.consultant.ru/.

[30] Compliance of English and Russian formulas in Excel (and vice versa!) + description of formulas // http://brusentsov.com/2009/12/27/3519. 